possessions at the time of his death. This "true and perfect Inventary" is on vellum and is about five inches broad and seventeen feet long. The skins, about thirty inches long, bear, each, a blue sixpenny stamp, and they are all sewn together. From this inventory we learn that Newton "left 362 books in Folio, 477 in Quarto, 1,057 in Octavo, duodecimo and 24 mo., together with above one hundred weight of pamphlets and wast books". The total of volumes was thus 1,896 . These were, we read, in six bookcases and were valued at $£ 270$. The lot of 858 volumes is offered for $£ 5,000$ and the copy of Barrow's Euclid

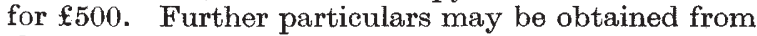
the vendors.

\section{Newton and Alchemy}

NEWTON has been regarded by a number of writers as a credulous alchemist. In some notes on Newton's chemical philosophy written upon the occasion of the tercentenary of his birth, Dr. D. McKie (Phil. Mag., 33,847 ; 1942) disputes this judgment. Newton's interest in chemistry probably began when he was lodging with Clark, the Grantham apothecary, while attending the King's School. He noted down interesting chemical recipes in his earliest note-books when he had a highly practical mind and great skill with his hands. Later on, in 1665 and in 1669, we have records that he bought chemical apparatus and materials. At this time, too, he experimented on the production of alloys that would take a high polish and would therefore be suitable for use as mirrors in the reflecting telescope that he had recently designed. In considering whether Newton should be regarded as a chemist or as an alchemist, Dr. McKie examines Newton's own chemical writings, from which "it would be difficult to conclude that he was 'a credulous alchemist'. Rather, he appears as a pioneer in the study of chemical attraction, as in fact he appeared to many of those who came immediately after him and who held his 'Queries' in such high regard during the eighteenth century". As distinct from his own chemical writings, Newton copied out many long passages and made very extensive extracts from a large number of alchemical writings. Dr. McKie claims that too much significance has been put upon these extracts. Many of them were from rare books, and many alchemical books gave useful information on the properties of the metals and their compounds. Moreover, Newton copied out passages from books that were not alchemical. "We might also ask what man of science would care to be judged by what he had copied out of books." Newton's chemical thought set forth in his published writings shows an advance towards modern chemistry rather than a reversion to the already discredited pursuit of gold-making.

\section{Historical Method in Teaching Science}

Prof. J. Kenner, of the Manchester College of Technology, recently opened a discussion on the "Historical Method in Teaching Science" at a meeting of the Manchester Literary and Philosophical Society. Bearing in mind the need to produce able rather than merely learned men, Prof. Kenner examined the matter, first from the wider point of view of the problem of general education, and quoted from recent articles indicating failures caused by "inadequacy of outlook, a whole method of approach" and by lack of a creative and forward-looking spirit. If those failures are to be avoided in the future, he urged close examination of our educational scheme. If education be defined as deliberate adjustment to environment, he insisted that "if this environment is to be healthy, it must be progressive". Put more fully, his view was that education "should be conceived and designed as a training for life in a progressive environment", and each should contribute to its progress according to his ability. Prof. Kenner recommended that natural science should be taught as a record of progress and of the methods by which that progress has been achieved. Separate courses on the history of science are not necessary. It should be an integral part of teaching. Appreciation of science, its discipline, its procedure and its possibilities are not only useful intrinsically "but also as a criterion of proposed public policy in regard to it". One of the main difficulties in the War, Prof. Kenner pointed out, lies in the present examination requirements.

\section{Reconstruction. Problems in School and Home}

AN interim report has just been issued by the Electrical Association for Women giving the Association's point of view on post-war reconstruction as affecting education and careers, housing and kitchen planning, and electricity in the home, coupled with the design and performance of electrical apparatus and appliances. So far as education and careers are concerned, it is considered that school buildings must be designed for many age-groups, they should show a high æesthetic standard of design, be of high-grade materials, and pay proper attention to health and comfort. The school should be the centre of juvenile life and a meeting-place for parents and teachers. Greater consideration should be given to domestic subjects both for girls and boys, so that domestic science shall take its rightful place, providing training for new careers in the post-war world and a basis for citizenship. As regards housing and kitchen planning, homes should be designed to meet the varying requirements of different types of occupants-. families, single persons, the aged, etc. Public services such as electricity, main water and drainage, and telephones should be universally available.

In the sphere of electrical equipment, it is pointed out that electricity as a source of domestic power is increasingly popular with housewives who want etficiency and economy. Standardization of voltage, current, apparatus, and accessories such as plugs, sockets, switches, connectors is desired. Table-type cookers and refrigerators should generally be installed in order to avoid stooping. Every newly built home should have its built-in refrigerating unit. Good kitchen lighting is imperative. Women want efficiency instead of 'ornamentation'; they are even prepared to forgo variety if good design and performance is within the reach of all. These are the salient features in the report, collated by Elsie E. Edwards, which is the culmination of two years study by women in all parts of Great Britain.

\section{Livestock Management and Public Health}

Ar a meeting of the Backs to the Land Club on March 25, the subject of hygiene in connexion with domestic food production was discussed. Prof. J. W. Munro said that scientific men would be willing to tackle any problems that 'backyarders' might be confronted with in the avoidance of public nuisance. Mr. W. MeA. Gracie, director of Infestation Control at the Ministry of Food, referred to the problem of rats, and it was agreed that by making knowledge 
of their movements available, householders could render greater assistance than by isolated and spasmodic attempts at destruction. Pig keepers and poultry keepers contributed to the discussion by giving their experiences of livestock management in built-up areas, and suggested standards that might be laid down to protect public health and amenities after the War. It was agreed that while a measure of livestock keeping is necessary to maintain soil fertility, the disposal of small amounts of manure presents a difficult problem. Some pig clubs have got over the difficulty by composting. The subjects of food storage and insect pests associated with the different classes of livestock were referred to. The chairman, Mr. John Green, said that at law livestock keeping is permitted anywhere provided it does not amount to a nuisance, but that following a number of cases at the end of the last century, many public authorities had passed by-laws under the Public Health Acts, restricting these enterprises.

\section{Phenology of 1942}

WITH admirable promptitude in these difficult times, the fifty-second annual phenological report of the Royal Meteorological Society has been issued, covering the observations on the weather and fauna and flora in Britain from December 1941 to November 1942. This is interesting because the cold spring included the coldest February in England and Wales since 1895 , and the dry period in summer included a thirty-two days drought, the longest for thirteen years. It was an abundant year for crops and wild and cultivated fruits of almost every kind, while grass fields appeared exceptionally green in the autumn and the season was sufficiently free from frosts to produce a wealth of autumn tints, many oaks keeping their foliage in sheltered places into December. Migrant birds were uniformly late in reaching the most northerly zone in spring, but the cuckoo was the only bird to be late in all three zones, the other zones showing first migrant arrivals in advance of the average dates. 1942 was a year of comparative scarcity of immigrant Lepidoptera, especially of the painted lady butterfly, although some localities had considerable arrivals, and three migrant insects, the red admiral butterfly and the silver $\mathrm{Y}$ and convolvulus hawk moths, were recorded in the Shetlands.

Two hundred and sixty-four observers sent in their records, a slight reduction on previous years. It is noted that in order to arrive at a high degree of accuracy in average values for plant and insect dates, there should be revisions at intervals of five or ten years ; also that weather responses in different districts must be analysed separately when the meteorological characteristics of the season differ in those districts. Responses depend on the incidence of the weather in relation to the average dates, so that they are not necessarily uniform. The zone diagrams show that there is less difference in date between groups, as a whole, in different zones, than there is between the dates from observing stations in individual groups : the former may amount to a few days but the latter to a few weeks.

\section{Gifts to Universities of Leeds and Sheffield}

A FEW weeks ago, it was announced that $\mathrm{Mr}$. Henry Ellison had given the University of Leeds $£ 50,000$ to create an endowment fund for the provision of post-graduate fellowships for research in pure and applied chemistry and physics (see NATURE, March 13, p. 303). He has now put the scientific world further in his debt by a gift of $£ 25,000$, spread over seven years, to the University of Sheffield, with the suggestion that the money be expended during the years immediately following the War on a scientific research fellowship. Mr. Ellison, who is chairman of the Yorkshire Tar Distillers, Ltd., and has been associated for many years with the Sheffield Chemical Company and the Mirvale Chemical Company, is an old student of the Yorkshire College, the forerunner of the University of Leeds. His gifts, besides being of direct service to the industries in which he is himself directly interested, form a notable addition to the resources available in Great Britain for scientific research.

\section{Co-operative Systems in European Agriculture}

ThE British Association, through its Division for the Social and International Relations of Science, is arranging a conference on "Co-operative Systems in European Agriculture", to be held on Friday and Saturday, April 16 and 17, at the Royal Institute of International Affairs, Chatham House, St. James's Square, S.W.1, by kind permission of the Institute. The Conference will be opened by Sir Richard Gregory, president of the Association, and there will be four sessions, the subjects of which will be cooperation in three groups of European countries (north, west and east), and immediate relief after the War. Tickets of admission will be obtainable from the British Association, Burlington House, London, W.1.

\section{Announcements}

Sir Harold Hartuey has been appointed general treasurer of the British Association as from April 1, the beginning of a new financial year. He succeeds Prof. P. G. H. Boswell, who has resigned after twelve years service in office, first as a general secretary (1931-35), and then as general treasurer (1935-43). The gratitude due from the Association to Prof. Boswell has been acknowledged in a resolution by the General Committee.

At the annual general meeting of the Institution of Chemical Engineers, on April 2, the following medals for 1942 were presented : Osborne Reynolds Medal, Mr. L. O. Newton; Moulton Medal, Mr. W. K. Hutchison and Dr. E. Spivey, for their paper on "Design and Performance of Cooling Towers"; Junior Moulton Medal and Auard, Dr. S. H. Wade, for his paper on "Evaporation of Liquids in Currents of Air"; William Macnab Medals, Mr.J.H. Sharp and Mr. F. J. Wilkins.

The Committee on Africa, the War and Peace Aims has issued as a supplement to "The Atlantic Charter and Africa from an American Standpoint" a compilation by Rev. Dr. E. W. Smith entitled "Events in African History". This is a chronology in two parts, ancient and modern, with an index mainly of references to persons, places and organizations, with some subject entries. The modern chronology which occupies the greater part of the brochure is in three sections covering, respectively, the period of unrestricted slave-trade, 14151807 ; the period of struggle to extirpate slave-trade and slavery; exploration; partition; preliminary economic development; and expansion of Christianity (1807-1918); and the period of trusteeship (1919-1942). 